\title{
The digitalization as a global trend and growth factor of the modern economy
}

\author{
Olena Kravchenko ${ }^{1}$, Maryna Leshchenko, ${ }^{2,}$, Dariia Marushchak $^{2}$, Yuriy Vdovychenko $^{2}$, and Svitlana Boguslavska ${ }^{1}$ \\ ${ }^{1}$ Cherkasy Bohdan Khmelnytsky National University, Department of Management and Economic Security, Cherkasy, Ukraine \\ ${ }^{2}$ Cherkasy State Technological University, Department of International Economics and Business, Cherkasy, Ukraine
}

\begin{abstract}
The phenomenon of the digitalization in the world economy is investigated in the article. The digital economy is the most important engine of innovation, competitiveness and economic growth in the world. The specific features of the modern digital economy are determined. The main indicators of measuring the level of digital economy are analyzed, the world countries' leaders are defined. Study shows that each of the indexes has different methodological approaches to determining the level of digitalization and contains various factors. Highly developed countries have the best level of digitization of their own economies, because they have high-quality access to the Internet, a high level of scientific and technological capacity development and wide information access. The indicators of Ukraine as a digital economy are analyzed. Article shows that Ukraine as a European country is only at the beginning of its development of a high-quality digital economy. The links between national economy's macroeconomic indicators development connecting with innovations are established.
\end{abstract}

Today, economic growth is impossible without using of information and communication technologies, because they are covering increasingly various spheres of economic activities and creating new opportunities for socio-economic development. Globalization, transformation of consumer behavior, mobility, availability of information are the trends of our time. Digital technologies are radically reshaping the global economic system. The formation of an effective digital economy will open significant opportunities for the creation and development of business, it will help to increase investment flows, accumulation of human and financial resources of the world.

The concept of "digital economy" first appeared in 1995 , as this year was previously defined as a turning point in the production of equipment for information technology. Moreover, at that time Internet emerged as a significant source of "free" content [1, p. 2].

Throughout history, the economy has been transformed by revolutionary inventions (telegraph, railway, car). The difference with the Internet is that it is inherently global, used by both developed and developing countries. John Sviokla said "the Internet is one of the most complex things ever created. It takes human organization to another level. Thus, the digital economy will launch the third wave of capitalism, that will transform business and government and lead to the creation of extraordinary wealth around the world" [2, p. 6].

The universal term "the third industrial revolution" has gained great popularity, the main ideologues of which are the researchers Jeremy Rifkin [3] and Raymond Kurzweil [4], that provides for the gradual introduction of a whole complex of new technological solutions (including renewable / clean energy sources, composite and nanomaterials, biomedical innovations, 3D printing technologies, mass electrification of transport etc.) $[3,4]$.

The core of the digital economy is the "digital sector": the IT / ICT industry that produces fundamental digital goods and services. This "digital economy" is defined as "part of an economic outcome derived solely or primarily from digital technologies with a business model based on digital goods or services" - consists of the digital sector and also new digital and platform services. The increased use is the using of ICT in all sectors of the economy, this is the "digital economy" [5].

The development of the digital economy can generally be described as the process by which information technologies, such as the Internet or other means of communication, change economic and social relations in such a way that a number of barriers in international economic relations disappear altogether or minimize. In this context, it is worth mentioning the statement of T. Friedman, the essence of which is that new technologies have the ability to unite the world by forming their own strong links through a combination of production, research and marketing processes in different countries at the same time and maintain control over these processes through the latest means of communication [6]. Computerization covers all the tools that have led to the progress of society and its transition from industrial to information. It is worth remembering the concept of "information" society of D. Bell, when knowledge and information become the main, inexhaustible, renewable resource [7]. And the information itself is a public good and is characterized by all the properties that are inherent in them, namely, accessibility for a wide range of consumers and exceptional competitiveness. This is what

*Corresponding author: mari.leshchenko@gmail.com 
ensures the rapid development of information resources, and they become at the same time the basis for the development of the modern digital economy.

The digital economy is growing rapidly on a global scale. It is the most important engine of innovation, competitiveness and economic growth in the world. The main products of the digital economy are the same goods and services of the traditional economy that is provided by computer equipment and digital systems such as the global Internet. This has its advantages, the main of which is to increase the availability of ordinary users to certain markets (goods or services), not only large companies, reduce transaction costs, increase efficiency and competitiveness.

The characteristic feature of the digital economy is its connection with the economy on demand (on-demand economy), which provides for not the sale of goods and services, but access to them at the moment when it is needed. The advantages of the economy on demand are: high speed of obtaining the necessary services or goods; reducing their cost for the end-user by reducing the number of intermediaries; simplifying the output of suppliers of goods and services to users [8, p. 14].

The review of the digital Agenda for Europe (DAE) [9] highlighted the impact of digital technologies on work and growth, noting that the Internet provides people with the opportunity to create and disseminate their ideas, creating new content, entrepreneurs and markets.

Modern tools for the study of the level of digitalization covers a variety of techniques. In particular, the main indices characterizing the world digitalization include: Digital Evolution Index, DiGiX, Networked Readiness Index, IMD World Competitiveness, DESI, Bloomberg Innovation Index and ICT Development Index. Each index has different methodological approaches to determining the level of digitalization and contains different factors that help to investigate. For example, the Digital Evolution Index shows how different countries are moving from the physical past to the digital future, and offers simple tools to determine which countries are the most ready for the transition, how quickly they are updated, and whether some are better located than some others. The Digital Evolution Index analyzes the main indicators that govern the digitization of the country: delivery conditions, demand conditions, institutional environment and innovation and change. To get an overview of the digital readiness and competitiveness of countries, the index divides these indicators into 12 components measured using a total amount of 108 indicators [10]. Networked Readiness Index is an indicator of the world economic forum, which characterizes the level of development of information and communication technologies in the world [11]. NRI consists of three components: the ICT environment proposed by a particular country or community, the readiness of key stakeholders (individuals, businesses and governments) to use ICT, and finally the use of ICT among these stakeholders The DiGiX index is an index of digitization that evaluates the factors, behavior of agents and institutions that enable the country to fully use information and communication technology (ICT) to enhance competitiveness and well-being. It is a complex index that summarizes the corresponding figures in 100 countries. DiGiX consists of six main components: infrastructure, adoption of households, adoption of enterprises, costs, regulation and maintenance [12]. The index of digital economy and society (DESI) measures progress in EU countries in reference to the digital economy and society. It combines a set of relevant indicators of European digital policy [13].The structure of the index consists of 5 main indices, containing subindexes, giving accurate knowledge about the level of digitalization, such as ICT connectivity, digital skills, indicators, use of the Internet, integration into digital technologies, indicators of development of the electronic environment.

IMD World Competitiveness Center creating the rating takes as a basis such indicators as knowledge, technology and the future readiness of countries to implement digital technologies [14].

In general, comparing the ratings of countries, according to different methods and indicators, we can see that the TOP-10 countries in every ratings changes because the overall calculation of the digitalization of economy is carried out on different indicators (Table 1).

Global trends of digitalization of the economy show that highly developed countries have the best level of digitization of their own economies because they are characterized by high-quality access to the Internet (broadband and mobile Internet), a high level of development of scientific and technological potential and wide information access. Among the regions of the world (World Bank), the largest number of Internet users are in Europe and Central Asia. Today, about $75 \%$ of the total population of Europe and Central Asia use the Internet. This indicator reaches $50 \%$ in other regions [15].

Among the member of the participating countries of the European Union, the best access indicators have such countries as Denmark, Germany, Luxembourg, Sweden and the UK. In General, it can be seen that another group of EU member have at least $60 \%$ of all households, this says about high level of automation and ease of life. Such countries as the Czech Republic, Latvia and Italy have less indicators.

An integral part of digital Commerce is e-Commerce, it simplifies the purchase and sale for both buyers and sellers. This reduces the chain from seller to buyer and it is easier to purchase. The 5 largest e-Commerce markets include:

1.China: $\$ 672$ billion, share of e-Commerce in total retail sales $-15.9 \%$;

2.United States: $\$ 340$ billion, share of e-Commerce in total retail sales $-7.5 \%$;

3.UK: $\$ 99$ billion, share of e-Commerce in total retail sales $-14.5 \%$;

4. Japan: \$ 79 billion, share of e-Commerce in total retail sales $-5.4 \%$;

5. Germany: $\$ 73$ billion, share of e-Commerce in total retail sales is $8.4 \%[16]$.

The global trend shows that the main means of payment are credit cards (Asia and North America), in second place is a digital payment system, this is a platform of electronic means that can be used in any calculations (Western Europe and China). Another 
popular method is debit cards (Africa)

The majority of online purchases were made from manufacturers located on the same continent: Europe
(63.4\%), the Pacific region of Asia (57.9\%), Africa (55.5\%), Latin America (54.6\%) and North America $(45.5 \%)$.

Table 1. The Top-10 economies on the level of digitalization in different indexes.

\begin{tabular}{|c|l|l|l|l|l|l|l|}
\hline Place & $\begin{array}{c}\text { Digital Evolution } \\
\text { Index }\end{array}$ & $\begin{array}{c}\text { IMD Digital } \\
\text { Competitiveness }\end{array}$ & \multicolumn{1}{|c|}{ DiGix } & DESI(EU) & $\begin{array}{c}\text { Bloomberg } \\
\text { Innovation Index }\end{array}$ & $\begin{array}{c}\text { ICT Development } \\
\text { Index }\end{array}$ & $\begin{array}{c}\text { Networked } \\
\text { Readiness Index }\end{array}$ \\
\hline 1 & Norway & Singapore & Luxembourg & Denmark & South Korea & Iceland & Singapore \\
\hline 2 & Sweden & Sweden & Great Britain & Finland & Sweden & Korea & Finland \\
\hline 3 & Switzerland & USA & Hong Kong & Sweden & Singapore & Switzerland & Sweden \\
\hline 4 & Denmark & Finland & USA & Netherlands & Germany & Denmark & Norway \\
\hline 5 & Finland & Denmark & Netherlands & Luxembourg & Switzerland & USA & USA \\
\hline 6 & Singapore & Netherlands & Japan & Belgium & Japan & Hong Kong & Netherlands \\
\hline 7 & South Korea & Hong Kong & Singapore & Great Britain & Finland & Netherlands & Switzerland \\
\hline 8 & Great Britain & Switzerland & Norway & Ireland & Denmark & Norway & Great Britain \\
\hline 9 & Hong Kong & Canada & Finland & Romania & France & Luxembourg & Luxembourg \\
\hline 10 & USA & Norway & Sweden & Bulgaria & Israel & Japan & Japan \\
\hline
\end{tabular}

It is expected that retail sales of e-Commerce will rise to 4.058 trillion in 2020 , which is $14.6 \%$ of the total retail spending in 2015.

The increase of the number and quality of telecommunications use also has a great impact on digitalization. Global telecommunications revenues had decreased by $4 \%$ between 2015 and 2016, falling by $\$ 1.9$ trillion.

Developing countries experienced complex annual growth rate of $6.6 \%$ in telecommunications revenues between 2008 and 2016, while developed countries experienced a decline of $-0.8 \%$ in the same period. Developing countries have $83 \%$ of the world's population, they receive only $39 \%$ of the world's income from telecommunications [17].

It is worth noting that the European Union presents many opportunities and challenges associated with the rapid development of the digital economy, the rapid growth of data flows, the dominance of the USA firms, security concerns and new business models in many sectors. The digital transformation of business and society in the EU represents a huge potential for Europe.

An important indicator characterizes the state of the digital economy in the $\mathrm{EU}$ are the indicators of entrepreneurship through the Internet. The activity of entrepreneurs through the Internet is an integral part of the modern world market trade. Internet activity does not only facilitate trade, but it also helps quickly to accumulate and mobilize revenues.

In the EU, between 2008 and 2016, the share of enterprises that used electronic turnover increased by $7 \%$, and the volume of sales of enterprises, due to electronic sales, increased by 6 percentage points.

During 2016, 44\% of large enterprises carried out electronic sales, which corresponds to $26 \%$ of the total turnover of this class. Similarly, $29 \%$ of medium-sized enterprises carried out electronic sales, which corresponds to $13 \%$ of the total turnover of this value. On the contrary, $18 \%$ of small enterprises engaged in electronic sales, and that is only $7 \%$ of the turnover of such enterprises [18].

Such countries as the Czech Republic (5.6\%), Ireland (5.9\%), Slovakia (6.6\%) and the UK (4.7\%) demonstrated the development of e-Commerce, which contributes of business development. In such EU member countries as
Belgium (-2.9\%), Luxembourg (-3.1\%), Netherlands ($6 \%)$, Lithuania $(-3 \%)$ and Portugal $(-2.7 \%)$ negative indicators were observed [19].

Ukraine, as a European country, is only at the beginning of its path to creating a high-quality digital economy. Despite the fact that Ukrainian IT specialists are in great demand on the world labor market, undeveloped infrastructure, "outdated technologies", lack of legislation and the target direction in the government is a great obstacle for creating the necessary conditions of digitalization for the national economy.

Ukraine takes only the 85th place among the countries in the world in the World Economic Forum. According to the components Ukraine has the following positions: the number of Internet users - 80th place, Internet connection - 64th, Internet bandwidth - 68th place, mobile Internet connection - 131st. Unfortunately, Ukraine has worsened its ICT indicators of use for the last two components (Table 2).

Table 2. Ukraine's position in the ranking of the world Economic Forum, 2016-2017 [20, 21].

\begin{tabular}{|l|c|c|c|c|}
\hline \multirow{2}{*}{ Indicator } & \multicolumn{2}{|c|}{$2016-2017$} & \multicolumn{2}{c|}{$2015-2016$} \\
\cline { 2 - 5 } & Place & Indicator & Place & Indicator \\
\hline Technological development & & & & \\
\hline $\begin{array}{l}\text { Technological adaptation } \\
\text { (borrowing, perception) }\end{array}$ & 85 & 3.6 & 86 & 3.45 \\
\hline $\begin{array}{l}\text { Availability of the most } \\
\text { modern technologies }\end{array}$ & 93 & 4.3 & 96 & 4.3 \\
\hline $\begin{array}{l}\text { Technological absorption of } \\
\text { corporate level }\end{array}$ & 74 & 4.4 & 100 & 4.2 \\
\hline FDI and technology transfer & 115 & 3.7 & 117 & 3.8 \\
\hline The use of ICT & & & & \\
\hline Internet users & 80 & 49.3 & 80 & 53.4 \\
\hline $\begin{array}{l}\text { Broadband Internet } \\
\text { connection }\end{array}$ & 64 & 11.8 & 72 & 8.4 \\
\hline Bandwidth & 68 & 45.7 & 64 & 40.7 \\
\hline Mobile broadband connection & 130 & 8.1 & 121 & 7.5 \\
\hline
\end{tabular}

In Bloomberg Innovation Index 2017 Ukraine has fallen to the 4th position for the year, taking forty-sixth place. Ukraine is ahead of Cyprus, South Africa, Iran and Morocco. It was on the 33rd place in 2015. In the Networked Readiness Index Ukraine occupies 64th place (Table 3). 
Table 3. Ukraine in the world rankings of digitalization of the economy, 2017.

\begin{tabular}{|c|c|c|c|}
\hline Index & Place & Index & Place \\
\hline $\begin{array}{l}\text { Networked Readiness } \\
\text { Index }\end{array}$ & $\mathrm{x}$ & DESI (EU) & $\mathrm{x}$ \\
\hline $\begin{array}{c}\text { IMD Digital } \\
\text { Competitiveness }\end{array}$ & 85 & $\begin{array}{l}\text { Bloomberg Innovation } \\
\text { Index }\end{array}$ & 46 \\
\hline DiGix & 87 & $\begin{array}{l}\text { ICT Development } \\
\text { Index }\end{array}$ & 79 \\
\hline
\end{tabular}

Since Ukraine is not a member of the European Union, it is not possible to study its level in the DESI rating. Also, it is not possible to analyze its level in the Digital Evolution Index.

One of the main reasons is the lack of relevant indicators, this does not allow to study the level of digitalization and innovative development, and as a result to explore the real competitiveness of the state. It is also important to determine how the digitization of economic spheres affects the overall economic performance of the country. To do this, you can use the correlation, it means the connection, the relationship between objectively existing phenomena. Using correlation and regression analysis, we construct a model of the relationship of GDP per capita $(y)$ with factors that significantly affect the level of digitalization of the economy, namely fixed broadband subscription $\left(x_{1}\right)$, individual use of the Internet $\left(x_{2}\right)$, capital investment in software and databases $\left(x_{3}\right)$, innovation in industrial enterprises $\left(x_{4}\right)$, the total cost of innovation activities $\left(x_{5}\right)$, technical grants $\left(x_{6}\right)$, export of ICT services $\left(x_{7}\right)-$ dependent variables. After constructing the correlation matrix, we obtained a value that provides information about the materiality of the relationship and the dependent variables and the resulting indicator and between the dependent variables (Table 4).

Analyzing the value of the matrix of pair correlation coefficients, it can be confirmed that factors such as $x_{1}, x_{2}$, $x_{5}$ have a significant direct linear relationship with the resulting indicator $(r x y>0.65)$. With regard to other factors, it can not be confirmed that the resulting indicator is uniquely linearly depends on them. As a result of testing of $x$-indicators for multicolinearity, we excluded from further research $x_{1}$ (fixed broadband subscription), $x_{2}$ (individual use of Internet) and $x_{7}$ (export of ICT services).

As a result we get regression equation:

$$
y=2942.037+0.04 x_{3}-118.18 x_{4}+0.14 x_{5}-2.66 x_{6} .
$$

Calculate the coefficient of multiple correlation and determination:

$R x y=0.935154509-$ correlation between $x_{i}$ and $y$ is strong enough;

$d=0.874513955-87.4 \%$ of GDP per capita depends on the investigated factors, and other $12.6 \%$ of the factors were not investigated in the model.

Check the model adequacy using the $F$-criteria: $F_{\text {calculated }}=41.814$ when $F_{\text {tabular }}=3.55$, as $F_{\text {calculated }}>F_{\text {tabular }}$, so this means the model is adequate in terms of statistical data.

Having determined the elasticity coefficients, we can say that the elasticity coefficient with a value of
0.08482325 indicates that if capital investments in software and databases $\left(x_{3}\right)$ will grow by $1 \%$, then GDP per capita $(y)$ will increase by $8.5 \%$. If the introduction of innovations in industrial enterprises $\left(x_{4}\right)$ grow by $1 \%$, the GDP per capita $(y)$ will decrease by $75 \%$. If the total amount of costs in the areas of innovation $\left(x_{5}\right)$ grow by $1 \%$, the GDP per capita $(y)$ will increase by $51.6 \%$. If technical grants $\left(x_{6}\right)$ grow by $1 \%$, GDP per capita $(y)$ will decrease by $30.6 \%$.

Table 4. The coefficients of pair regression.

\begin{tabular}{|c|c|c|c|c|c|c|c|c|}
\hline & 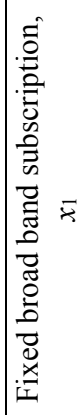 & 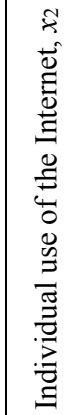 & 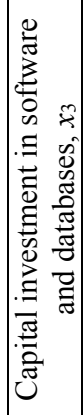 & 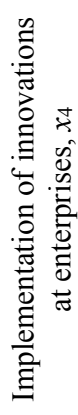 & 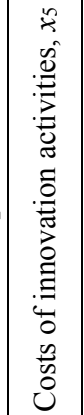 & 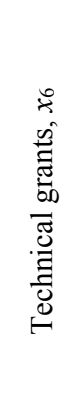 & 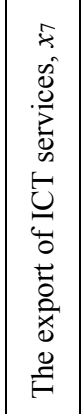 & 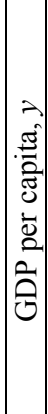 \\
\hline $\begin{array}{l}\text { Fixed broad } \\
\text { band } \\
\text { subscription, } x_{1}\end{array}$ & 1 & & & & & & & \\
\hline $\begin{array}{l}\text { Individual use } \\
\text { of the Internet, } \\
x_{2}\end{array}$ & 0.992 & 1 & & & & & & \\
\hline $\begin{array}{l}\text { Capital } \\
\text { investment in } \\
\text { software and } \\
\text { databases, } x_{3} \\
\end{array}$ & 0.463 & 0.441 & 1 & & & & & \\
\hline $\begin{array}{l}\text { Implementation } \\
\text { of innovations } \\
\text { at enterprises, } \\
x_{4}\end{array}$ & 0.373 & 0.354 & 0.096 & & & & & \\
\hline \begin{tabular}{|l|} 
Costs of \\
innovation \\
activities, $x_{5}$
\end{tabular} & 0.761 & 0.736 & 0.525 & 0.154 & 1 & & & \\
\hline $\begin{array}{l}\text { Technical } \\
\text { grants, } x_{6}\end{array}$ & 0.175 & 0.187 & 0.253 & 0.178 & 0.066 & 1 & & \\
\hline $\begin{array}{l}\text { The export of } \\
\text { ICT services, } \\
x_{7}\end{array}$ & 0.947 & 0.945 & 0.464 & 0.517 & 0.707 & 0.107 & 1 & \\
\hline $\begin{array}{l}\text { GDP per } \\
\text { capita, } y\end{array}$ & 0.671 & 0.657 & 0.336 & -0.137 & 0.639 & -0.168 & 0.556 & \\
\hline
\end{tabular}

Thus, the digital revolution develops network communications over the administrative borders of countries and territories, which accelerates the transition of the world to a decentralized, distributed model of production. In the future, the development of ICT can reduce the cost of international logistics, as well as stimulate the development of offshoring.

According to empirical researches conducted by McKinsey Global Institute, digitalization of the economy can be no less powerful tool to improve its productivity and competitiveness than creating technological innovations [22].

This means that all countries, and especially those that have embarked on the path of catching-up development, have a chance for a rapid breakthrough in productivity growth if they focus on the broad informatization of 
society and the effective implementation in business process of already existing ICT in the world, but not only on the creation of their own breakthrough technologies in certain directions.

\section{References}

1. Jorgenson, D.W.: Information technology and the U.S. economy. Am. Econ. Rev. 91(1), 1-32 (2001)

2. The new digital economy. How it will transform business.

http:/www.citibank.com/transactionservices/home/ docs/the_new_digital_economy.pdf Accessed 10 Jan 2019

(2011).

3. Rifkin, J.: The third industrial revolution: how lateral power is transforming energy, the economy, and the world. Palgrave Macmillan, New York (2011)

4. Kurzweil, R.: The law of accelerating returns. http://www.kurzweilai.net/the-law-of-acceleratingreturns\%3E (2001). Accessed 5 Dec 2018

5. Ivanova, V.V.: Informatsiinyi rynok: zarubizhni i ukrainski realii (Information market: foreign and Ukrainian realities). Actual problems of ekonomics. 2, 39-43 (2009)

6. Friedman, T.: Lexus şi măslinul. Cum să înţelegem globalizarea. Editura Fundaţiei PRO, Bucureşti (2001)

7. Bell, D.: The coming of post-industrial society. A venture in social forecasting. Basic Books, New York (2001)

8. Karcheva, G., Ogorodnya, D., Openko, V.: Tsyfrova ekonomika ta yii vplyv na rozvytok natsionalnoi ta mizhnarodnoi ekonomiky (Digital economy and its impact on the development of the national economy). https://fp.cibs.ubs.edu.ua/files/1703/17kgttme.pdf (2017). Accessed 24 Jan 2019

9. Fact Sheets on the European Union: Digital Agenda for Europe. http://www.europarl.europa.eu/factsheets/en/sheet/6 4/digital-agenda-for-europe (2019). Accessed 20 Jan 2019

10. Digital Planet 2017: How Competitiveness and Trust in Digital Economies Vary Across the World. https://sites.tufts.edu/digitalplanet/dei17 (2017). Accessed 17 Dec 2018

11. Networked Readiness Index. Global Information Technology Report. http://reports.weforum.org/global-informationtechnology-report-2016/networked-readiness-index (2016). Accessed 05 Dec 2018

12. Cámara, N., Tuesta, D.: DiGiX: The Digitization Index. https://www.bbvaresearch.com/wpcontent/uploads/2017/02/WP 17-

03_DiGiX_methodology.pdf ${ }^{-}$(2017). Accessed 15 Dec 2018

13. DESI 2018. Digital Economy and Society Index. Methodological note. http://ec.europa.eu/information_society/newsroom/i mage/document/2018-20/desi-2018methodology_E886EDCA-B32A-AEFB07F5911DE975477B 52297.pdf (2018). Accessed 07 Feb 2019

14. IMD World Digital Competitiveness Ranking 2017. https://data.worldbank.org (2017). Accessed 08 Jan 2019

15. World bank open data. https://data.worldbank.org (2017). Accessed 02 Feb 2019

16. Global Ecommerce Platforms 2017: A Country-byCountry Review of the Top Retail Ecommerce Sites. eMarketer Report (2017)

17. World Telecommunication/ICT Indicators Database. https://www.itu-ilibrary.org/science-andtechnology/data/world-telecommunication-ictindicators-database_pub_series/database/2a8478f7en (2017). Accessed $21 \overline{\text { Mar }} 2019$

18. Digital Economy and Society Index. Methodological note, http://ec.europa.eu/eurostat/data/database (2017). Accessed 02 Dec 2018

19. Eurostat/European Commission. https://ec.europa.eu/eurostat/data/database (2018) . Accessed 21 Mar 2019

20. Schwab, K.: World Economic Forum: The Global Competitiveness Report 2016-2017. http://www3.weforum.org/docs/GCR20162017/05FullReport/TheGlobalCompetitivenessRepo rt2016-2017_FINAL.pdf (2017). Accessed 18 Nov 2018

21. Schwab, K.: World Economic Forum: The Global Competitiveness Report 2015-2016. http://www3.weforum.org/docs/gcr/20152016/Global Competitiveness Report 20152016.pdf (2016). Accessed 25 Dec 2018

22. Manyika, J., Lund, S., Bughin, J., Woetzel, J., Stamenov, K., Dhingra, D.: Digital globalization: The new era of global flows. https://www.mckinsey.com/ /media/McKinsey/Busi ness\%20Functions/McKinsey\%20Digital/Our\%20In sights/Digital\%20globalization\%20The\%20new\%2 0era\%20of\%20global\%20flows/MGI-Digitalglobalization-Full-report.ashx (2016). Accessed 07 Feb 2019 